Medical Scope Journal (MSJ). 2019;1(1):26-30

Available from: https://ejournal.unsrat.ac.id/index.php/msj

\title{
Gambaran Keluhan Muskuloskeletal serta Faktor Risikonya pada Online Gamer di Warung Internet Kota Manado
}

\author{
Nadya B. Supit, Lery F. Suoth, Woodford B. S. Joseph
}

Fakultas Kesehatan Masyarakat Universitas Sam Ratulangi Manado

Email: supitnadya14@gmail.com

\begin{abstract}
Musculoskeletal complaint in skeletal muscles could vary from mild to very severe. This study was aimed to obtain the profile of musculoskeletal complaints and their risk factors among online gamers at internet cafés in Manado. The involved risk factors were, as follows: work posture, body size, and smoking habit. This was a quantitative study with a descriptive observational method. Respondents were obtained by using non random sampling with a purposive sampling technique. There were 40 respondents involved in this study. Based on the level of musculoskeletal complaints, 3 respondents (7.5\%) had mild musculoskeletal complaints, 27 respondents (67.5\%) had moderate musculoskeletal complaints, and 10 respondents (25.0\%) had severe musculoskeletal complaints. Based on sitting position, there were 6 respondents (15.0\%) with moderate risk, 23 respondents (57.5\%) with high risk, and 11 respondents (27.5\%) with very high risk. Based on body size, there were 5 underweight respondents (12.5\%), 30 normal weight respondents (75.0\%), 3 overweight respondents (7.5\%), and 2 obese respondents (5.0\%). Smoking habit was found in 32 respondents (77.5\%). In conclusion, most of the online gamers had moderate musculoskeletal complaints, high risk sitting position, normal weight, and smoking habit.
\end{abstract}

Keywords: musculoskeletal complaints, risk factors, online gamers

\begin{abstract}
Abstrak: Keluhan muskuloskeletal merupakan keluhan yang dirasakan pada otot skeletal bervariasi dari yang ringan sampai ke parah. Penelitian ini bertujuan untuk mendapatkan gambaran keluhan muskuloskeletal serta faktor-faktor risikoya pada online gamer di warung internet Kota Manado. Faktor-faktor risiko yang dibahas ialah posisi kerja, ukuran tubuh, dan kebiasaan merokok. Jenis penelitian ialah kuantitatif, dengan model penelitian observasi deskriptif. Responden penelitian diperoleh menggunakan non random sampling dengan teknik purposive sampling dan didapatkan sebanyak 40 online gamer. Hasil penelitian memperlihatkan bahwa berdasarkan tingkat keluhan muskuloskeletal: ringan sebanyak 3 orang (7,5\%); sedang sebanyak 27 orang (67,5\%); dan berat sebanyak 10 orang (25,0\%). Berdasarkan posisi duduk diperoleh risiko sedang pada 6 orang (15,0\%); risiko tinggi pada 23 orang (57,5\%); dan risiko sangat tinggi pada 11 orang (27,5\%). Berdasarkan ukuran tubuh diperoleh yang kurus berjumlah 5 orang (12,5\%); normal, berjumlah 30 orang $(75,0 \%)$; kegemukan, berjumlah 3 orang (7,5\%); dan obesitas berjumlah 2 orang (5,0\%). Berdasarkan kebiasaan merokok diperoleh yang merokok berjumlah 32 orang (77,5\%) dan yang tidak merokok berjumlah 8 orang (22,5\%). Simpulan penelitian ini ialah sebagian besar online gamer dengan keluhan muskuloskeletal sedang, posisi duduk berisiko tinggi, ukuran tubuh normal, dan kebiasaan merokok.
\end{abstract}

Kata kunci: keluhan muskuloskeletal, faktor risiko, online gamer

\section{PENDAHULUAN}

Keluhan muskuloskeletal merupakan keluhan yang dirasakan pada otot skeletal dari keluhan yang ringan sampai parah. Studi tentang keluhan muskuloskeletal pada berbagai jenis aktivitas kerja 
menunjukkan bahwa keluhan otot yang sering dirasakan antara lain pada otot leher, bahu, lengan, tangan, jari, punggung, pinggang, dan otot-otot bagian bawah. ${ }^{1}$

Bureau of Labour Statistics (BLS) di Amerika melaporkan bahwa pada tahun 2007 terdapat sebanyak 29 gangguan muskuloskeletal dari semua cedera akibat kerja. ${ }^{2}$ International Labour Organization (ILO) pada taun 2013 dalam program The prevention of occupational disease menyebutkan bahwa musculoskeletal diseases (MSDs) termasuk carpal tunnel syndrome mewakili 59\% dari keseluruhan catatan penyakit yang ditemkan pada tahun $2005 \mathrm{di}$ Eropah. Di Korea, keluhan muskuloskeletal mengalami peningkatan yang sangat tinggi dari 1.634 pada tahun 2001 menjadi 5.502 pada tahun 2010. ${ }^{3}$

Keluhan musculoskeletal pada umumnya terjadi karena kontraksi otot berlebihan akibat pemberian beban kerja yang terlalu berat dengan durasi pembebanan yang panjang. Keluhan otot kemungkinan tidak terjadi bila kontraksi otot hanya berkisar antara 15-20\% dari kekuatan otot maksimum. Namun bila kontraksi otot melebihi $20 \%$, maka peredaran darah ke otot berkurang menurut tingkat kontraksi yang dipengaruhi oleh besarnya tenaga yang diperlukan. Pasokan oksigen ke otot menurun, proses metabolisme karbohidrat terhambat dan sebagai akibatnya terjadi penimbunan asam laktat yang menyebabkan timbulnya nyeri otot. ${ }^{1}$

Terdapat beberapa faktor yang menyebabkan terjadinya keluhan muskuloskeletal antara lain faktor penyebab pekerjaan, lingkungan, dan individu. Penyebab pekerjaan yaitu peregangan otot berlebihan, aktivitas berulang, atau sikap kerja tidak alamiah. Penyebab lingkungan yaitu, tekanan, getaran, dan mikroklimat. Penyebab kombinasi dan faktor individu seperti usia, jenis kelamin, kebiasaan merokok, aktivitas fisik, kekuatan fisik dan ukuran tubuh sangat berperan dalam hal terjainya keluhan muskuloskeletal. ${ }^{1}$

Penelitian yang dilakukan oleh Pantoiyo et $\mathrm{al}^{4}$ terkait dengan sikap kerja dan keluhan muskuloskeletal pada pegawai pengguna personal komputer di kantor BPJS Ketenagakerjaan Cabang Manado melaporkan bahwa sikap kerja pegawai sebanyak 57,1\% dengan tingkat risiko pekerjaan sedang, 35,7\% risiko pekerjaan tinggi, dan $7,1 \%$ risiko pekerjaan sangat tinggi. Boshuizen et al menyatakan bahwa terdapat hubungan bermakna antara kebiasaan merokok dengan keluhan otot pinggang, khususnya untuk pekerjaan yang memerlukan pengerahan otot. ${ }^{1}$ Penelitian oleh Kamurahan et $\mathrm{al}^{5}$ meyebutkan bahwa terdapat hubungan bermakna antara status gizi (ukuran tubuh) dengan keluhan muskuloskeletal pada nelayan di Desa Kalinaun Kecamatan Likupang Timur Kabupaten Minahasa Utara.

Penelitian ini dilakukan di warung internet yang ada di Kota Manado. Warung internet merupakan tempat atau kios yang memiliki banyak komputer dan banyak gamer melakukan kegiatan bermain. Online gamer merupakan sebuah hobi yang diminati oleh berbagai kalangan tidak hanya muda dan dewasa, namun juga pada anak kecil baik laki-laki maupun perempuan. Online gamer menghabiskan waktu di depan komputer dan tentunya mengakibatkan kelelahan sehingga terjadi keluhan muskuloskeletal. Online gamer yang ada di warnet bukanlah pekerja tetapi mereka hanya menyalurkan hobinya.

Berdasarkan hasil survei awal dengan melakukan wawancara dan observasi pada online gamer di Kota Manado didapatkan bahwa mereka sering merasakan nyeri pada pergelangan, lengan, leher, punggung atas (bahu), dan punggung bawah (pinggang). Pada penelitian ini diambil 3 faktor yang paling memengaruhi keluhan muskuloskeletal yaitu posisi kerja, ukuran tubuh, dan kebiasaan merokok.

\section{METODE PENELITIAN}

Penelitian ini dilakukan di warung internet di Kota Manado Jenis penelitian ialah kuantitatif, dengan model penelitian survei yang bersifat deskriptif. Populasi dalam penelitian ini ialah seluruh online gamer yang menggunakan komputer; jumlah populasi tidak diketahui dengan 
pasti. Sampel diambil sebanyak 40 orang dengan menggunakan teknik purposive sampling. ${ }^{5}$ Instrumen penelitian yang digunakan ialah kuisioner Nordic Body Map (NBM) dan lembar penilaian RULA. Analisis data yang digunakan yaitu analisis univariat untuk mengetahui gam-baran keluhan muskuloskeletal serta faktor risiko.

\section{HASIL PENELITIAN}

Responden penelitian ini berusia 18-25 tahun dan yang terbanyak yaitu responden berusia 18 tahun berjumlah 12 orang (30,0\%) dan yang paling sedikit ialah responden berusia 19, 20, dan 24 tahun; masing-masing berjumlah 3 orang (7,5\%). Responden terbanyak ialah yang bermain selama 5-7 jam berjumlah 18 orang (45,0\%) dan yang paling sedikit ialah responden bermain selama 8-10 jam berjumlah 2 orang (5,0\%).

Tabel 1 memperlihatkan bahwa yang paling banyak yaitu responden yang tingkat risiko keluhan muskuloskeletal sedang berjumlah 27 orang $(67,5 \%)$ dan yang paling sedikit ialah responden dengan tingkat risiko keluhan muskuloskeletal rendah berjumlah 3 orang (7,5\%).

Tabel 1. Distribusi responden berdasarkan tingkat keluhan muskuloskeletal

\begin{tabular}{ccc}
\hline $\begin{array}{c}\text { Tingkat keluhan } \\
\text { muskuloskeletal }\end{array}$ & n & $\mathbf{\%}$ \\
\hline Rendah & 3 & 7,5 \\
Sedang & 27 & 67,5 \\
Tinggi & 10 & 25,0 \\
Sangat tinggi & 0 & 0 \\
Jumlah & 40 & 100 \\
\hline
\end{tabular}

Tabel 2 memaparkan bahwa yang paling banyak yaitu responden dengan tingkat risiko posisi kerja yang tinggi berjumlah 23 orang (57,5\%), dan yang paling sedikit ialah responden dengan tingkat risiko posisi kerja yang sedang berjumlah 6 orang (15,0\%).

Tabel 3 menjelaskan bahwa yang paling banyak yaitu responden berukuran tubuh normal sebanyak 30 orang $(75,0 \%)$ dan yang paling sedikit ialah responden obes berjumlah 2 orang (5,0\%).

Tabel 2. Distribusi responden berdasarkan tingkat risiko posisi kerja

\begin{tabular}{ccc}
\hline $\begin{array}{c}\text { Tingkat risiko } \\
\text { posisi kerja }\end{array}$ & n & \% \\
\hline Rendah & 0 & 0 \\
Sedang & 6 & 15,0 \\
Tinggi & 23 & 57,5 \\
Sangat tinggi & 11 & 27,5 \\
Jumlah & 40 & 100 \\
\hline
\end{tabular}

Tabel 3. Distribusi responden menurut ukuran tubuh

\begin{tabular}{ccc}
\hline Ukuran tubuh & $\mathbf{n}$ & $\mathbf{\%}$ \\
\hline Kurus & 5 & 12,5 \\
Normal & 30 & 75,0 \\
Kegemukan & 3 & 7,5 \\
Obesitas & 2 & 5,0 \\
Jumlah & 40 & 100 \\
\hline
\end{tabular}

Tabel 4 menjelaskan bahwa yang paling banyak yaitu responden yang merokok berjumlah 32 orang (77,5\%) dan yang paling sedikit ialah responden tidak merokok berjumlah 8 orang (22,5\%).

Tabel 4 Distribusi responden menurut kebiasaan merokok

\begin{tabular}{ccc}
\hline Merokok & $\mathbf{n}$ & $\mathbf{\%}$ \\
\hline Ya & 32 & 80,0 \\
Tidak & 8 & 20,0 \\
Jumlah & 40 & 100 \\
\hline
\end{tabular}

\section{BAHASAN}

Hasil penelitian mendapatkan bahwa untuk tingkat keluhan rendah belum diperlukan tindakan perbaikan; untuk tingkat keluhan sedang diperlukan tindakan di kemudian hari; dan untuk tingkat keluhan tinggi diperlukan tindakan segera.

Berdasarkan observasi pada saat penelitian kebanyakan online gamer tidak bersandar pada sandaran kursi. Karakteristik responden yang lama bermain paling banyak yang bermain selama 5-7 jam (45,0\%). Lama bermain dapat memicu terjadinya keluhan muskuloskeletal karena 
aktivitas yang dilakukan oleh online gamer monoton atau melihat terus pada layar komputer. Jenis keluhan muskuloskeletal yang terbanyak dirasakan ialah nyeri pada bagian leher atas dan tengkuk diakibatkan posisi duduk yang tidak ergonomis. Karena meja dan tempat duduknya tidak sesuai dengan ukuran tubuh online gamer maka kebanyakan online gamer akan membungkuk dan menunduk untuk menyesuaikan dengan layar komputer.

Posisi kerja merupakan salah satu faktor yang memengaruhi keluhan muskuloskeletal. Pengukuran posisi kerja dilakukan dengan cara metode penilaian RULA. Metode penilaian RULA menggunakan target postur tubuh untuk mengetimasi terjadinya risiko gangguan sistem muskuloskeletal, khususnya pada anggota tubuh

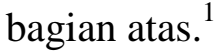

Hasil penelitian menunjukkan bahwa tindakan yang akan dilakukan untuk risiko tinggi memerlukan adanya investigasi dan perbaikan segera; untuk risiko sangat tinggi diperlukan adanya investigasi dan perbaikan secepat mungkin, sedangkan untuk risiko sedang diperlukan investigasi lebih lanjut, mungkin diperlukan adanya perubahan untuk perbaikan sikap kerja.

Ukuran tubuh merupakan penilai pertumbuhan seseorang untuk menilai status gizi. Pengukuran dilakukan berdasarkan Indeks Masa Tubuh (IMT) dengan mengukur tinggi badan per berat badan. ${ }^{6}$ Indeks ini merupakan alat atau cara yang sederhana untuk memantau status gizi orang dewasa, khususnya yang berkaitan dengan kekurangan dan kelebihan berat badan. Berat badan kurang dapat meningkatkan risiko terhadap penyakit infeksi, sedangkan berat badan lebih akan meningkatkan risiko terhadap penyakit degeneratif. $^{7}$

Keluhan pada sistem muskuloskeletal yang terkait dengan ukuran tubuh lebih disebabkan oleh kondisi keseimbangan struktur rangka dalam menerima beban, baik beban berat tubuh maupun beban tambahan lainnya. ${ }^{1}$ Indeks massa tuabuh yang tidak normal salah satu disebabkan karena kurangnya olaraga, pola makan dan kebiasaan hidup.

Seorang pekerja yang perokok pada saat bekerja akan mudah lelah karena kandungan oksigen dalam darah rendah, pembakaran karbohidrat terhambat, terjadi tumpukan asam laktat dan akhirnya timbul rasa nyeri otot. ${ }^{1}$ Hasil penelitian menunjukkan bawah sebagian besar responden merokok. Pada sebagian responden ditanyakan alasan merokok dan sebagian besar menjawab karena pergaulan dan lingkugan. Pertanyaan tersebut ditanyakan karna kebanyakan responden berusia 18 tahun yang sudah tidak berstatus sebagai siswa dan baru saja selesai dari sekolah menegah atas.

\section{SIMPULAN}

Berdasarkan hasil penelitian ini dapat disimpulkan bahwa sebagian besar online gamer dengan keluhan muskuloskeletal sedang, posisi duduk berisiko tinggi, ukuran tubuh normal, dan kebiasaan merokok.

Bagi warung internet disarankan untuk memberikan fasilitas tempat duduk yang bisa diatur posisi tinggi kursi agar dapat menyesuaikan dengan ukuran tubuh online gamer. Bagi online gamer sebaiknya melakukan relaksasi peregangan otot atau istirahat sebentar. Online gamer sebaiknya selalu memperhatikan status gizi, menjaga kesegaran jasmani, dan istirahat cukup. Bagi peneliti selanjutnya, diharapkan dapat mengkaji faktor-fator lain selain tiga faktor yang dibahas pada penelitian ini serta mencari hubungannya dengan keluhan musculoskeletal.

\section{DAFTAR PUSTAKA}

1. Tarwaka. Ergonomi Industri: Dasar-dasar Pengetahuan Ergonomi dan Aplikasi di Tempat Kerja (Revisi 2nd ed). Surakarta: Harapan Press, 2015.

2. Bureau of Labor Statistics. 2008. Musculoskeletal disorders and days away from work in 2007. U.S. Department of Labor, The Economics Daily. [cited 2019 June 14]. Available from: https://www.bls.gov/opub/ted/2008/d ec/wk1/art02.htm.

3. International Labour Organization. The Prevention of Occupational Diseases. 
30 Medical Scope Journal (MSJ), Volume 1, Nomor 1, Juli-Desember 2019, hlm.26-30

Switzerland: International Labour Organization (ILO), 2013.

4. Pantoiyo WI., Pinontoan O, Josephus J. Gambaran lama kerja, sikap kerja dan keluhan muskuloskeletal pada pengguna personal computer di Kantor BPJS Ketenagakerjaan Cabang Manado. Jurnal Kesehatan Masyarakat. 2016;8(3):1-8.

5. Kamurahan EM, Malonda NH, Sondakh RC. Hubungan antara status gizi dan sikap kerja dengan keluhan muskuloskeletal pada nelayan di Desa Kalinaun Kecamatan Likupang Timur Kabupaten Minahasa Utara. Jurnal Kesehatan Masyarakat. 2018;3(1):91-103.

6. Notoatmodjo S. Metodologi Penelitian Kesehatan. Jakarta: Rineka Cipta, 2012.

7. Triwibowo C, Pusphandani ME. Pengantar Dasar Ilmu Kesehatan Masyarakat. Yogyakarta: Nuha Medika, 2015. 